\title{
THE AMERICAN NEWSPAPER: A STUDY IN SOCIAL PSYCHOLOGY.
}

There is a widespread prejudice against the newspapers, based on the belief that they cannot be trusted to report truly the current events in the world's life on account of incompetence or venality. But in spite of this distrust we are almost altogether dependent upon them for our knowledge of widely interesting events. As the organization of society becomes more complex and far-reaching, the importance of the newspaper in the distribution of intelligence inevitably increases. The modern social man finds himself in much the same position as the ancient individual who first discovered confusion in his sensations and believed that his senses were deceiving him. The newspaper is to society much what sight and hearing are to the individual, and it is a momentous day when the community, overwhelmed with newspaper sensations, begins to doubt and to discriminate. The function of the newspaper in a wellordered society is to control the state through the authority of facts, not to drive nations and social classes headlong into war through the power of passion and prejudice.

The influence of the newspaper, especially the daily, is felt most in cities. There social organization is more complex, the problems of government are more acute, the people are readier to follow after some new thing, the individual is more immediately dependent on his fellows, than in the country. In cities the newspaper can deliver itself. Early every morning it blockades one's door, asking to be read, and every day on the streets and in the cars it clamorously assails those who go about their business. Under these conditions the newspaper, no longer sought so much as seeking, becomes a specially potent factor in city life, and, 
pandering as it often does to man's social passions, it fastens itself upon him and stimulates his mind to superficial and sometimes unhealthy interests.

The newspaper habit has many vicious consequences. The children in the public schools are often urged to read the papers and keep track of the world's news. And it cannot be denied that the newspaper serves an important end in bringing men to social consciousness and in giving them data upon which to form social judgments. But we must deplore and, so far as possible, overcome the evils of habitual newspaper reading. These evils are, chiefly, three: first, the waste of much time and mental energy in reading unimportant news and opinions, and premature, untrue, or imperfect accounts of important matters; second, the awakening of prejudices and the enkindling of passions through the partisan bias or commercial greed of newspaper managers; third, the loading of the mind with cheap literature and the development of an aversion for books and sustained thought. Thus the daily newspaper often tends to make the intellectual life of its readers one continuous series of petty excitements, a veritable life of the social "senses," and to shut their minds, by mere fulness of occupation, against any appeal that does not find a voice in the daily news sheet.

The daily newspaper is one of the many influences that make a city civilization different, for better and for worse, from a country civilization. And as the science of government is the science of the manipulation of social forces for the furtherance of public order and the common weal, the problems of city government can be solved only by insight into the peculiar characteristics of city people and of city life. The study of the newspaper as a factor in social organization is, therefore, of prime importance to those who are concerned with municipal affairs.

The development of modern journalism is a bewildering fact. The American Nezspaper Directory divides the 
papers into classes according to their accredited bona fide circulation, as follows:

Class A, circulation, . . . . . . . . . . 75,000 or more.

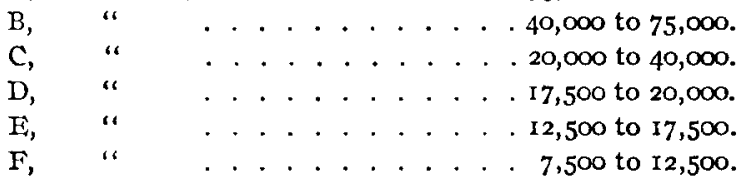

There are still other classes, which have a smaller circulation and include by far the larger number of dailies. But if we confine our attention to the six classes, $A$ to $F$, and if we count one morning and one afternoon edition as separate papers, we find that there were in 1897 , all told, 250 dailies having a circulation of 7,500 or more published in the United States. Of these papers, 224 are printed in English, twenty-two in German, two in Bohemian, one in Danish, and one in French. According to circulation these papers are distributed as follows:

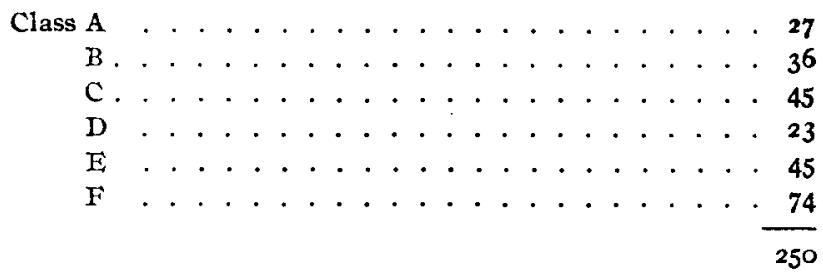

These 250 leading dailies are distributed among the diferent sections of the country as follows:

North Atlantic States . 113, or 6.5 per million of population.

South Atlantic States.

North Central States

. 14 , or 1.6

South Central States

. 89 , or 4.0 "

Western States $\cdot \cdot \cdot \cdot 19$,

United States . . 250 , or 4.0 "

Of the forty-five states in the Union there are sixteen which have no daily papers with an accredited circulation 
of 7,500. The states having the largest numbers of such papers are:

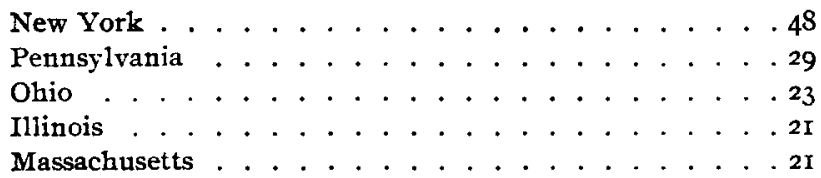

On the streets of New York City and its suburbs there are daily offered to the unsuspecting public newspapers which contain reading matter, exclusive of advertisements, sufficient to fill 4,000 or 5,000 pages of Economic Studies, and in the twenty-one principal news circles of the United States the papers publish every day, the equivalent of seventy books containing 100,000 words each. Fortunately for the public, the daily paper is, in the main, a local institution.

Every great city is a news centre. The possible constituency of a daily paper may be counted as comprising every one who lives within two or three hours' distance of the newspaper office. Nowadays, with our multiplied railroads and trolley lines, a daily paper may hope to have some direct popular influence over an area with a radius of, perhaps, fifty miles. The larger the population of this area, the more numerous, as a rule, are the papers published there; and the greater is the bulk of reading matter daily offered to the same constituency. In Detroit the citizen is beset by only four important dailies; in New York city be is beset by twenty or more. If we take the fiftymile radius as representing approximately the distance to which a daily paper may have a general sale, we shall have twenty-one principal news circles in the United States, including within their limits all of the cities which had a population of over 100,000 in 1890. A few of these circles include more than one such city. The accompanying table shows the twenty-one news circles with population 


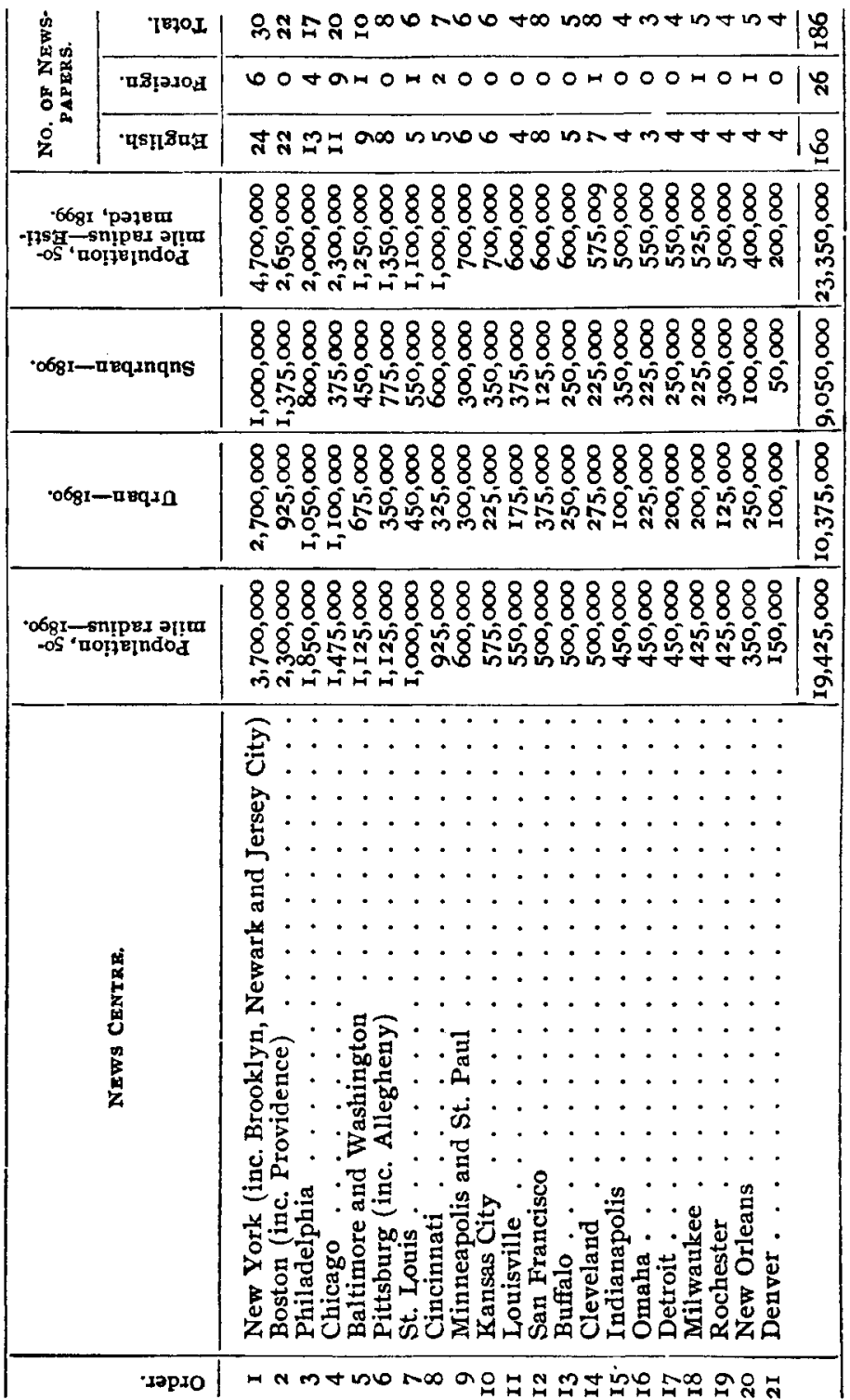


estimated from the census of 1890 , divided into urban and suburban, and roughly estimated for 1899 ; and the number of daily papers having at least 7,500 circulation, counting one morning and one afternoon edition (where there are such) as separate papers. These twenty-one news circles had in 1890 an aggregate population of nearly nineteen and one-half millions, or about 30 per cent of the total population of the United States, while they furnish 186 of the 250 dailies having largest circulation, or about 75 per cent, including all of the twenty-six leading dailies printed in a foreign language, and all but two of the papers having a circulation of more than 20,000 . It is clear that the larger the city the more serious is its newspaper problem, and the greater is the necessity for the organization of news and the cultivation of skill in reading newspapers.

No one nowadays reads a newspaper through, although possibly some readers feel conscience-smitten because they are unable to do so. Most readers look for what interests them, and are satisfied if they find it quickly. This one fact points the way along which the newspaper is developing and must continue to develop, and brings us to the problem of newspaper analysis. There are five general divisions under which newspaper matter falls. These are;

I. News.

II. Illustrations.

III. Literature.

IV. Opinion.

V. Advertisements.

Under "News" should be included every item that is a first-hand report of current events. "Illustrations" include all pictorial matter outside of advertisements. Under "Literature" are included serial stories, special studies, humorous sketches, jokes, poetry, book reviews, and foreign correspondence not in the nature of news. "Opinion" is made up of letters, exchanges and editorials. "Advertisements" are items of any kind for the printing of which 
the newspaper receives direct compensation, as well as business announcements made by the newspaper in its own behalf.

"News," for which the newspaper is named, generally occupies the largest share of space, and is made up of very heterogeneous elements. During the Spanish-American war -and the analysis which forms the basis of this essay was made of papers published at that time-the war news formed so large and so special a department-sometimes occupying more than one-fourth of the newspaper's entire space-as to deserve separate classification. Accordingly, under the head of "News" we have three main subdivisions-war news, general news, and special news. The distinction between general news and special news, though in some cases difficult of application, is nevertheless of first-rate importance. Briefly, general news is news that is edited; special news is news that is not edited. General news is reported inexactly, and sometimes incorrectly; special news is reported exactly, and men do business in reliance upon it. General news may be subdivided into foreign news, political news, news of crime and vice, and miscellaneous news. Special news may be subdivided into business news, sporting news, and society news. "Opinion" may be divided into editorials, which give expression to the newspaper's individual policy, and letters and exchanges, which express, in a more or less restricted way, public opinion in general. "Advertisements" may be separated into six classes-want, retail, medical, political and legal, miscellaneous, and self advertisements.

According to this analysis, the matter contained in the newspaper is arranged under eighteen heads, which may now be described more in detail:

1. War news includes news of the actual military operations of the combatants in the field; news of the organization and discipline of the army, of the movements of troops at home, of the camps, and of the food stipplies for the 
soldiers; news of legislation by Congress, and the general policy of the government in regard to war revenues and expenditures; news and notes referring to individuals brought into prominence by the war; and news of the foreign relations of the United States as affected by the war.

2. Foreign newes includes reports of all current events in foreign countries which are not connected with our own wars, and which are reported on account of their international interest. This separate classification of foreign news would be illogical except on the hypothesis that society is, on the whole, organized with reference to political divisions.

3. Political news includes news of current administration and legislation in nation, commonwealth, and city, as well as news of party conventions, candidates, and speeches, of conferences and discussions calculated to influence political action, and of elections.

4. News of crime and vice includes accounts of the commission of crimes and of the trial and punishment of criminals, and news of suicides, brawls, drunkenness, prostitution, divorce proceedings, etc.

5. Miscellaneous newes includes reports of celebrations and meetings, some personal notes, general news of trusts, labor unions, and strikes, religious news, and other general news not included under preceding heads.

6. Business nezes includes regular reports of organized business life, news of the markets, financial and commercial, insurance notes, railway notes, court calendars and legal news, shipping news, real estate news, and weather bulletins.

7. Sporting newes includes news of baseball, football, golf, cycling, cricket, chess, billiards, prize-fighting, yachting, and all sports of recognized general interest.

8. Society news, the least definite of the divisions under special news, includes a number of items ranging from obituary and marriage lists through reports of music and 
the drama, to more general news of "society" as it is at Newport and elsewhere.

9. Illustrations include cartoons, illustrative sketches, and portraits. Cartoons comprise all pictorial caricatures and humorous representations giving point to the news of the day. Sketches include drawings of buildings and scenes, whether illustrative of crime or of war, and all professedly bona fide illustrations of news and literature, other than portraits. Portraits are the pictures of "men of the hour" and persons "in the public eye," as well as of historical characters.

10. Literature includes the various kinds of matter enumerated in an earlier paragraph, and ranges between wide extremes in both quantity and quality. Many "exchanges" should, perhaps, be classed under this head, but on account of the difficulty of sorting them, all exchanges are classed together under a later head.

I I. Editorials include the editor's comments upon current events, news summaries on the editorial page, and editorial articles on science, literature and art.

12. Letters and exchanges include all signed communications to the editor from the general public, and all articles or items copied from other journals. This division does not include signed news correspondence or the dispatches of the Associated Press or of news syndicates.

I3. Want advertisements include those so designated by the papers themselves and, in general, most of the advertisements occupying only a few lines each and placed together in columns of nearly solid printed matter.

14. Retail advertisements include chiefly the large mass of advertisements calculated to attract local custom to mercantile establishments, and represent roughly the attractions of the "shopping district."

15. Medical advertisements include advertisements of sanitariums, special treatments, and patent medicines ranging from "Cuticura Soap" to "'Paine's Celery Compound." 
Advertisements of this class often refer to sexual disorders, and thinly-veiled announcements of criminal medical practice not infrequently appear.

I6. Political and legal advertisements include reports and notices the publication of which is required by law, whether paid for out of the public treasury or by individuals. The proceedings of municipal and county legislative boards, lists of delinquent taxes, and notices of sheriff sales, mortgage foreclosures, and the like, make up the bulk of this division.

17. Miscellaneous advertisements are composed, chiefly, of transportation, financial, educational, amusement, hotel, and summer resort advertisements. This division of advertisements corresponds roughly to the "business" division of special news.

I8. Self advertisements include notices referring to price, circulation, the Sunday issue, some special feature, or other topics for announcement or self-gratulation.

The writer has received sample copies of 240 of the 250 leading dailies already described. Of 186 published in the twenty-one principal news circles, $147^{-1} 3^{6}$ English and eleven foreign-have been analyzed in detail. In this analysis, each paper was examined column by column and the amount of matter coming under the several subdivisions was estimated down to the twentieth of a column. The totals under each subdivision were reduced to percentages of the whole, and the papers in each news circle were compared. General percentages were made out for the papers in each news circle taken in aggregate, and by comparison of news circles, averages for the whole country were obtained. The copies analyzed were, for the most part, issues for some day in June, 18.98, but quite a number bear date, September, 1898, and a few were issued in other months. In addition to this analysis of single copies, a full week's issues in September, r898, and also in Septem- 
ber, 1899, of two great dailies, the New York Times and the Chicago Record, were analyzed. All these papers were affected, though not in the same degree, by the existence of the war with Spain and the resulting complications in the Philippines. The general scheme of analysis is shown in an accompanying diagram.

Diagram-Analysis of the Newspaper.

\begin{tabular}{|c|c|c|c|c|c|c|}
\hline $\begin{array}{l}\text { Name of paper } \ldots \\
\text { Date } \\
\text { Circulation } \\
\text { Price per copy } \\
\text { Yearly subscription } \\
\text { Number of pages } \\
\text { Total number of columis }\end{array}$ & \multicolumn{2}{|c|}{$\begin{array}{l}\text { New York, } \\
\text { "Journal." } \\
\text { June } 11,1898 \\
1,213.751 \\
1 \text { cent } \\
18.50 \\
12 \\
84\end{array}$} & \multicolumn{2}{|c|}{$\begin{array}{c}\text { Chicago } \\
\text { "Times-Her- } \\
\text { ald." } \\
\text { June 6, } 1898 \\
\text { "A." } \\
\text { J cent } \\
\$ 6.00 \\
12 \\
84\end{array}$} & \multicolumn{2}{|c|}{$\begin{array}{c}\text { San Fraucisco } \\
\text { "Chronicle." } \\
\text { June }{ }^{1,1898} \\
4 \text { " } " \text { cents } \\
\$ 6.70 \\
12 \\
84\end{array}$} \\
\hline ANALYSIS OF CONTENTS. & 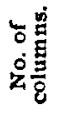 & 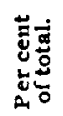 & 它咅 & 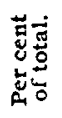 & 岁离 & 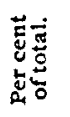 \\
\hline 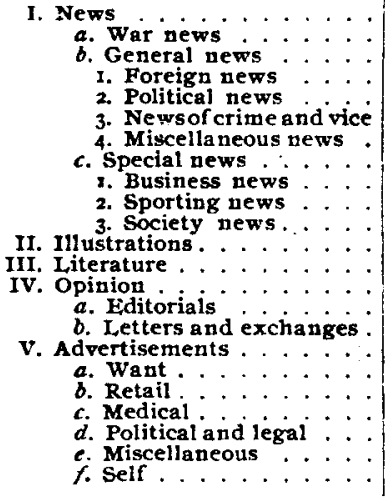 & $\begin{array}{c}32.35 \\
18.85 \\
8.1 \\
1.05 \\
1.45 \\
3.75 \\
1.85 \\
5.4 \\
2.5 \\
2.65 \\
.25 \\
15.75 \\
.5 \\
6.85 \\
6.85 \\
0.0 \\
28.55 \\
7.75 \\
7.65 \\
3.65 \\
0.0 \\
8.5 \\
1 .\end{array}$ & $\begin{array}{r}38.5 \\
22.4 \\
9.6 \\
1.2 \\
1.7 \\
4.5 \\
2.2 \\
6.5 \\
3 . \\
3.2 \\
18.3 \\
18.7 \\
.6 \\
8.2 \\
8.2 \\
0.0 \\
34 . \\
9.2 \\
9.1 \\
4.4 \\
0.0 \\
10.1 \\
1.2\end{array}$ & $\begin{array}{c}53.55 \\
19.8 \\
15.45 \\
.45 \\
6.15 \\
.3 \\
8.55 \\
18.3 \\
10 . \\
5.45 \\
2.85 \\
2.2 \\
2.25 \\
6.85 \\
3.75 \\
3.1 \\
19.15 \\
2.5 \\
6 . \\
2.1 \\
.45 \\
7.7 \\
.4\end{array}$ & $\begin{array}{r}63.7 \\
23.5 \\
18.4 \\
.5 \\
7.3 \\
.4 \\
10.2 \\
21.8 \\
11.9 \\
6.5 \\
3.4 \\
2.6 \\
2.7 \\
8.2 \\
4.5 \\
3.7 \\
22.8 \\
3 . \\
7.1 \\
2.5 \\
.5 \\
9.2 \\
.5\end{array}$ & $\begin{array}{c}43-55 \\
16.45 \\
15.5 \\
.35 \\
7.9 \\
2.2 \\
5.05 \\
11.6 \\
9.1 \\
1.65 \\
.85 \\
8.5 \\
0.0 \\
2.55 \\
2.45 \\
.1 \\
29.4 \\
9.5 \\
3.25 \\
3.4 \\
.1 \\
10.45 \\
2.7\end{array}$ & $\begin{array}{r}51.8 \\
19.5 \\
38.5 \\
.4 \\
9.4 \\
2.7 \\
6 . \\
13.8 \\
10.8 \\
2 . \\
1 . \\
10.1 \\
0.0 \\
3.1 \\
3 . \\
.1 \\
35 . \\
11.3 \\
3.9 \\
4.9 \\
12.1 \\
3.5 \\
3.2\end{array}$ \\
\hline
\end{tabular}

The various kinds of newspaper matter were found to occupy on the average for the whole country the following percentages of the total space: 


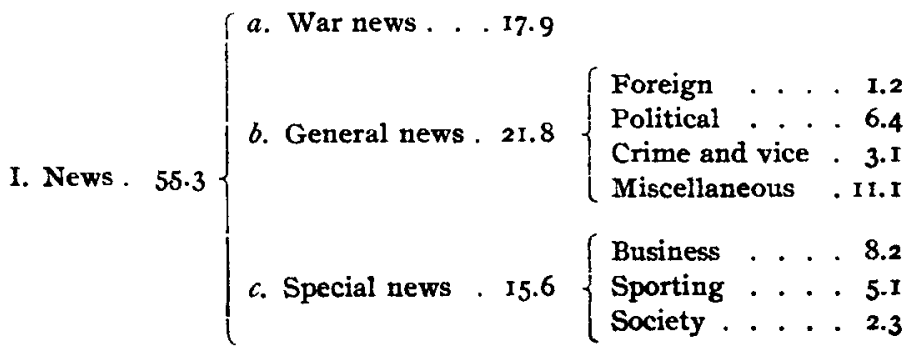

II. Illustrations $\ldots . .3 .1$

III. Literature . . . 2.4

IV. Opinion ..... $7.1 \begin{cases}a . \text { Editorials . . . . . . . . } & 3.9 \\ b \text {. Letters and exchanges } & 3.2\end{cases}$

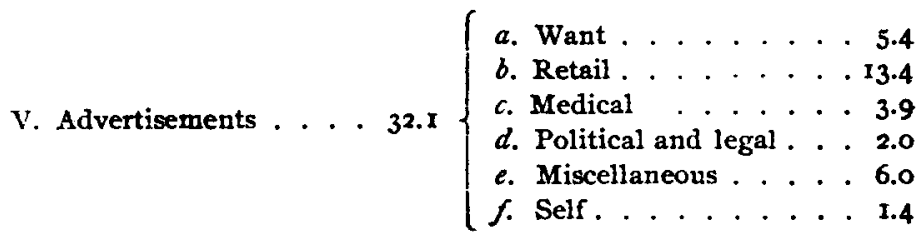

The analysis of individual papers shows " $I$,iterature" entirely wanting more frequently than any other class of matter. "Illustrations'" are also quite frequently wanting. "News," "Opinion," and "Advertisements" are the three grand divisions of matter that are never wholly lacking. It should, perhaps, be remarked that news of crime and vice, on account of which the newspaper is so often denounced, fills on the average only 3. I per cent of the whole space, though the percentage ranges in individual papers from zero to 18.8 , both extremes being found in New York city.

The percentages of space occupied by the various classes of matter in each of the twenty-one principal news circles are shown in the accompanying table. In some cases we 


\begin{tabular}{|c|c|c|c|c|c|c|c|c|}
\hline News CRNTRES. & 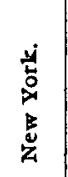 & 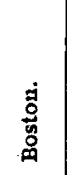 & & 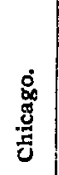 & 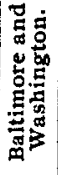 & $\begin{array}{l}\dot{8} \\
\text { 泀 } \\
\text { 苛 }\end{array}$ & $\begin{array}{l}\dot{m} \\
\dot{H} \\
\dot{H} \\
\dot{u}\end{array}$ & 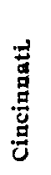 \\
\hline Number of dailies analyzed . . . . & 27 & 12 & 14 & 10 & 8 & 8 & 5 & \\
\hline Total number of columns . . . . . & 1,936 & 1,014 & 1,044 & 742 & 666 & 594 & $35^{8}$ & 298 \\
\hline Percentage of total space . . . . & 100 & 100 & 100 & 100 & 100 & 100 & 100 & 100 \\
\hline$\ldots \ldots$ & $55 \cdot 7$ & 53.9 & 58.4 & 50 & 53.7 & 52.3 & 60.1 & 63.3 \\
\hline$a$. War News $\ldots \ldots \ldots$ & I5.7 & 19.6 & 18.3 & 25.7 & $\mathbf{8 8 . 2}$ & 17.3 & 15.2 & 15.9 \\
\hline b. General News . . . . . . & 22.6 & 21.7 & 22.1 & I6. 1 & 22.2 & 15.8 & 27.3 & 28.6 \\
\hline I. Foreign $\ldots \ldots \ldots \ldots$ & 2.8 & .6 & 1.9 & .9 & .6 & .7 & 2.0 & 1.4 \\
\hline 2. Political . . . . . . & 5.6 & 5.8 & $5 \cdot 7$ & 6.1 & 6.6 & 3.8 & 6.3 & 8.9 \\
\hline 3. Crime and vice $\ldots \ldots \ldots$ & 4.9 & 2.5 & 2.9 & 1.9 & 2.6 & $3 \cdot 4$ & 7.8 & 3.5 \\
\hline 4. Miscellaneous $\ldots \ldots \ldots$ & 9.3 & 12.8 & II.6 & 7.2 & 22.4 & 7.9 & II.2 & 14.8 \\
\hline$\varkappa_{\text {Special News } \ldots \ldots \ldots} \ldots \ldots$ & I7.4 & \pm 2.6 & I8.0 & 18.2 & I3.3 & $\mathbf{1 9 . 2}$ & I7.6 & 18.8 \\
\hline ı. Business . . . . . . . . & 7.6 & $4 \cdot 2$ & 7.7 & 10,6 & $5 . t$ & ro.r & I0.0 & I0.2 \\
\hline 2. Sporting . . . . . . & 6.0 & 6.2 & 5.6 & $5 \cdot 3$ & 5.7 & 5.2 & 5.6 & 6.4 \\
\hline 3. Society $\ldots \ldots \ldots \ldots$ & 3.8 & 2.2 & 4.7 & 2.3 & 2.5 & $3 \cdot 9$ & 2.0 & 2.2 \\
\hline II. Illustrations $\ldots \ldots \ldots$ & 4.4 & 5.2 & 3.0 & 3.9 & 2.3 & 1.9 & 5.2 & 3.8 \\
\hline III. Literature $\ldots \ldots \ldots$ & 2.9 & 2.9 & 3.4 & 4.9 & 1.2 & 2.7 & .7 & .1 \\
\hline IV. Opinion $\ldots \ldots \ldots$ & 7.1 & 7.2 & 6.6 & 6.7 & 7.0 & 5.4 & 3.8 & 3.8 \\
\hline a. Editorials $\ldots \ldots \ldots$ & 4.4 & 3.7 & 3.6 & 4.7 & 3.I & 3.2 & 3.0 & 2.9 \\
\hline b. Letters and Exchanges . . . . & 2.7 & 3.5 & 3.0 & 2.0 & 3.9 & 2.2 & .8 & .9 \\
\hline V. Advertisements $\ldots \ldots \ldots$ & 29.9 & 30.8 & 28.6 & 34.5 & 35.8 & $37-7$ & 30.2 & 29.0 \\
\hline a. Want $\ldots \ldots \ldots$ & 5.1 & $5 \cdot 5$ & 6.0 & $5 \cdot 5$ & $5 \cdot 5$ & 2.6 & 6.0 & 7.2 \\
\hline b. Retail $\ldots \ldots \ldots \ldots$ & 10.8 & II.8 & I2.I & 16.1 & 13.3 & 24.4 & 8.6 & 9.7 \\
\hline c. Medical $\ldots \ldots \ldots$ & 2.2 & 3.5 & I.5 & 3.8 & $3 \cdot 3$ & 4.0 & 4.3 & 5.6 \\
\hline d. Political and Legal . . . . & 2.8 & .8 & .5 & .5 & .9 & I.I & $3 \cdot 3$ & $\mathrm{I.4}$ \\
\hline e. Miscellaneous . . . . . . & 7.4 & $.7 \cdot 3$ & 7.5 & 7.6 & 10.6 & 5.1 & 6.7 & 3.9 \\
\hline$f$ Self $\ldots \ldots \ldots$ & I.6 & I.9 & I.o & I.O & 2.2 & .5 & $\mathbf{1 . 3}$ & $x .2$ \\
\hline
\end{tabular}




\begin{tabular}{|c|c|c|c|c|c|c|c|c|c|c|c|c|c|}
\hline 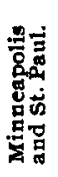 & 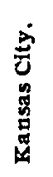 & 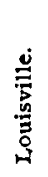 & 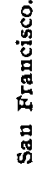 & 兽 & 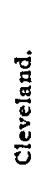 & 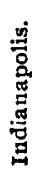 & 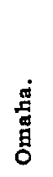 & 菅 & 岂 & 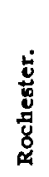 & 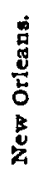 & 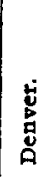 & 焉 \\
\hline 6 & 4 & 4 & 8 & 5 & 6 & 3 & 3 & 4 & 5 & 3 & 4 & 4 & \\
\hline 364 & 252 & 262 & 674 & 368 & 344 & 184 & 196 & 248 & 352 & 266 & 308 & 294 & \\
\hline 100 & 100 & 100 & 100 & 100 & 100 & 100 & 100 & 100 & 100 & 100 & 100 & 100 & \\
\hline 60.3 & 58.0 & 59.4 & 49.5 & 47. & 57.9 & 54.2 & 56.2 & 52.6 & 47.8 & 54.8 & 63.0 & 52.5 & $55 \cdot 3$ \\
\hline 24.3 & 21.4 & 19.8 & 17.6 & 75.5 & I4. I & 22.7 & II.O & 24.9 & I0.9 & 16.8 & 26.4 & 16.3 & 17.9 \\
\hline 20.1 & 20.3 & 20.2 & 18.3 & 14.7 & 28.4 & 16.7 & 34.6 & I7.I & 25.3 & 22.9 & 18.7 & 23.7 & 21.8 \\
\hline 1.6 & .8 & .7 & โ. 4 & .5 & 3.6 & .6 & 2.1 & .5 & .9 & .5 & .5 & .2 & 1.2 \\
\hline 3.2 & 6.8 & 6.0 & 6.3 & 6.9 & 7.8 & 4.0 & 11.0 & 3.3 & 6.0 & 7.5 & 10.2 & 7.3 & 6.4 \\
\hline 2.I & 3.3 & 3.5 & 4.2 & 2.1 & 4.5 & 1.8 & 2.3 & I.5 & x.0 & 3.8 & 2.6 & 2.4 & $3 . I$ \\
\hline 13.2 & 9.4 & 10.0 & 6.4 & 5.1 & I2.7 & I0.3 & Ig.1 & 11.8 & 17.4 & II.I & 5.4 & 13.8 & II.I \\
\hline 15.9 & 16.3 & 20.4 & 23.6 & 16.8 & 15.4 & $\tau_{4} .8$ & I0.6 & I0.6 & II.6 & 15.1 & 17.9 & 12.5 & 15.6 \\
\hline 9.3 & II. 0 & II.5 & 7.3 & 6.1 & 7.7 & 8.9 & 7.5 & 6.0 & 6.0 & 6.0 & 10.6 & 8.9 & 8.2 \\
\hline 4.0 & 4.3 & 7.0 & 3.4 & 7.9 & 5.8 & 4.1 & 2.6 & 3.8 & 3.6 & 7.2 & 5.0 & 2.3 & 5.1 \\
\hline 2.6 & 1.0 & 1.9 & 2.9 & 2.8 & x.9 & 1.8 & .5 & .8 & 2. & 1.9 & 2.3 & 1.3 & 2.3 \\
\hline 2.2 & 1.9 & 3.0 & 7.6 & .5 & 3.3 & 2.5 & .9 & 3.3 & 1.6 & .5 & 3.8 & 4.6 & $3 . \pi$ \\
\hline 3.4 & .8 & 1.5 & 2.6 & 8.6 & 3.7 & 2.7 & 3.8 & 2.7 & 6.2 & 9 & 1.3 & 2.4 & 2.4 \\
\hline 6.6 & 11.8 & $5 \cdot 3$ & 5.2 & 7.7 & 5.9 & 8.3 & 9.5 & 6.1 & 8.0 & 9.3 & 9.0 & 9.5 & 7.1 \\
\hline 3.7 & 4.2 & 3.8 & 3.2 & 4.3 & 4.6 & 3.9 & 4.7 & 3.4 & 4.1 & 4.8 & 5.9 & 4.0 & 3.9 \\
\hline 2.9 & 7.5 & I. 5 & 2. & 3.4 & 1.3 & 4.4 & 4.8 & 2.7 & 3.9 & 4.5 & 3.I & 5.5 & 3.2 \\
\hline 29.5 & 27.6 & 30.7 & 35.1 & 43.2 & 29.2 & 32.3 & 29.6 & 35.2 & 36.4 & 34.5 & 22.9 & 31.0 & $32 . I$ \\
\hline 4.8 & 4.1 & 3.4 & 7.9 & 4.5 & 5.7 & 7.3 & $7 \cdot 7$ & 7.7 & 4.8 & 3.4 & I.4 & 7.0 & 5.4 \\
\hline 9.8 & 13.9 & I9.7 & 5.4 & 21.0 & 11.7 & 15.7 & 9.3 & 14.0 & 17.5 & 17.0 & 5.7 & 14.8 & 13.4 \\
\hline 5.2 & $5 \cdot 3$ & 1.9 & 3.6 & 2.4 & 5.6 & 4.6 & 3.9 & 5.3 & 4.3 & 4.2 & 3.9 & 4.4 & 3.9 \\
\hline 3.7 & .9 & I & 6.5 & 7.5 & .9 & . I & .4 & 2.4 & 1.4 & 2.5 & 3.4 & . 1 & 2.0 \\
\hline 4.3 & 3.0 & 4.1 & 10.0 & 6.2 & $4 \cdot 3$ & 3.1 & 5.9 & 3.9 & 7.5 & 6.4 & 7.5 & 3.7 & 6.0 \\
\hline 1.7 & .4 & I. 5 & 1.7 & 1.6 & I.O & 1.5 & 2.4 & 1.9 & .9 & 1.0 & $\mathbf{1 . 0}$ & 1.0 & 3.4 \\
\hline
\end{tabular}


are able to detect interesting characteristics of local jourualism, as will appear from a rapid survey of the several centres:

1. New York, which is the metropolitan news centre of the country and has journals of all descriptions, "setting the pace" in "yellow" and conservative journalism alike, does not occupy either first or last place in any department. In foreign news it comes second, and would perhaps come first under normal conditions. In these statistics Cleveland stands first, as most of the papers analyzed for this news centre were issues for September, when the Dreyfus case and other foreign matters were taking up much space. New York stands second in crime and vice, and no doubt deserves that position. Individual New York papers, of course, show great variations. Following are the extremes in a number of departments:

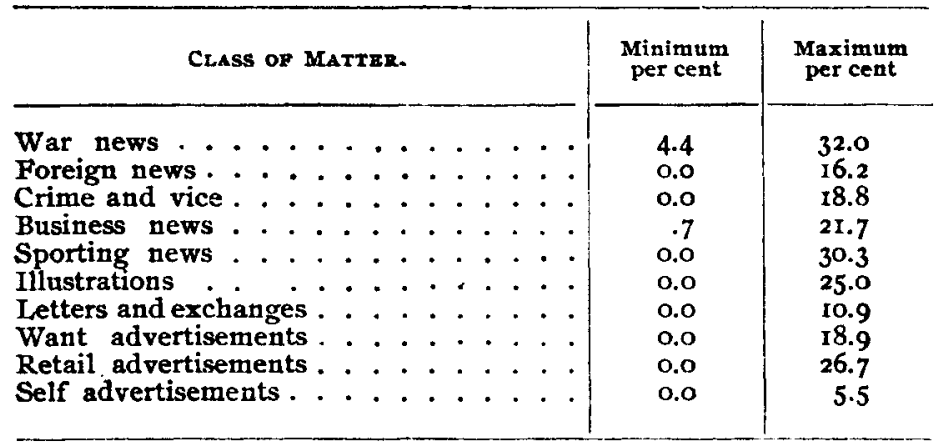

2. Boston, which is the one great news centre of New England, and which is supposed to be, more than any other large American city, the home of culture and learning, is nevertheless afflicted with sensational journalism. In percentage of illustrations this centre stands second. It is a curious fact that the craze for illustrations seems to have taken possession of the extreme West, the extreme East, and two or three intermediate stations, in the following 
order: San Francisco, Boston, St. Louis, Denver, New York. It is significant that Boston stands at the foot of the list in the department of business news. That Boston, too, shows wide variations in its individual papers will be seen by a comparison of the Evening Journal and the Evening Transcript:

\begin{tabular}{|c|c|c|c|c|c|c|c|}
\hline Class of & $M \Delta T$ & $T E R$ & & & & $\begin{array}{l}\text { Per cent in } \\
\text { "Journal }\end{array}$ & $\begin{array}{l}\text { Per cent in } \\
\text { "Trauscript. }\end{array}$ \\
\hline 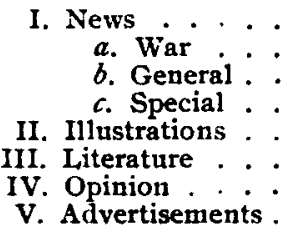 & $\begin{array}{l}\cdot: \\
: \\
: \\
: \\
: \\
: \\
:\end{array}$ & $\begin{array}{l}\dot{ } \\
: \\
\dot{ } \\
\dot{ } \\
\dot{ }\end{array}$ & $\begin{array}{l}\dot{.} \\
\dot{.} \\
\dot{.} \\
\dot{.}\end{array}$ & $\cdot$ & 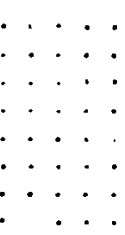 & $\begin{array}{r}69.5 \\
28.3 \\
18.5 \\
22.7 \\
4.7 \\
0.0 \\
8.9 \\
16.9\end{array}$ & $\begin{array}{r}41.4 \\
14.6 \\
17.6 \\
9.2 \\
0.0 \\
14.3 \\
10.6 \\
33.7\end{array}$ \\
\hline
\end{tabular}

3. Philadelphia, the most American of the great news centres, stands first in society news and last in medical advertisements, seemingly not a dishonorable distinction.

4. Chicago, the great industrial and commercial centre of the North Central states, stands second in literature and near the foot in crime and vice. While exhibiting no striking peculiarities as a news centre; Chicago furnishes, perbaps, the best average among its leading newspapers of any great city in the United States.

5. Baltimore and Washington show no very important peculiarities, except that they rank next to Boston at the bottom of the list in business news.

6. Pittsburg, with its immense suburban population, stands first in retail advertisements and next to the last in want advertisements.

7 and 8. St. Louis and Cincinnati, of which the one had in 1860 almost exactly 50 per cent and the other 45 per cent foreign-born population, predominantly German, seem now to be in some respects the most notable centres of "yellow 
journalism" in the country. These two centres keep remarkably close together in the table of percentages. Both stand high in illustrations, medical advertisements, and news of crime and vice; while they stand very low in letters and exchanges, editorials, literature, and retail advertisements. It is significant that Joseph Pulitzer, proprietor of the New York World, got his training in yellow journalism as manager of the St. Louis Post-Dispatch. There is, too, in both St. Louis and Cincinnati a member of the "Scripps-McRae League."

9. Minneapolis and St. Paul stand last in political news.

ro. Kansas City presents a considerable contrast with St. Louis in journalism, the former centre being nearly as conservative as the latter is sensational. Kansas City stands first in letters and exchanges and second in business news.

I I. Louisville stands first in business news and also first in the general subdivision, special news.

I2. San Francisco stands away above all the other news centres in the proportion of illustrations. It also stands first in want and last in retail advertisements, in these respects being almost the exact opposite of Pittsburg.

13. Buffalo takes first place in advertisements as a whole, and also in sporting news, while it stands very low in vice and crime and miscellaneous news.

14. Cleveland stands first in foreign news, second in medical advertisements, third in vice and crime, and near the last in war news. The relative prominence of foreign news and crime and vice, as well as the small importance of war news, are due to the fact that September issues for the most part were analyzed.

I5. Indianapolis stands low in crime and vice and in two divisions of advertisements.

I6. Omaha is a centre of extreme characteristics, standing first in political and miscellaneous news and self 
advertisements, last in social news, and next to the last in war and sporting news. The "Trans-Mississippi Exposition" accounts for the large percentage of miscellaneous news.

I7. Detroit takes second place in war news, and next to the last place in political and social news and crime and vice. In the general subdivision, special news, it stands at the foot of the list.

18. Milwaukee is first in literature, second in miscellaneous news and last in war news and crime and vice. The Wisconsin "Fifty-Years-of-Statehood" celebration affected Milwaukee papers much as the "Trans-Mississippi Exposition" did those of Omaha.

19. Rochester is second in sporting news and editorials and last in illustrations.

20. New Orleans has first place in war news and editorials, second place in political news, and last in advertisements as a whole. The high percentage of war news was probably due to the proximity of military operations.

2 I. Denver stands second in letters and exchanges, fourth in illustrations, and last in foreign and sporting news and miscellaneous advertisements.

Thus much has been said about differences between the contents of the newspapers of different localities, differences that are due partly to local and temporary events, partly to the influence of individual editors upon the character of journalism, and partly to the peculiar local characteristics of the newspaper constituencies.

An examination of the contents of papers arranged in classes according to circulation shows some interesting results. In news of crime and vice, in illustrations, and in want and medical advertisements, the percentages of space occupied show an almost steady increase with increase of circulation, while the opposite is true in political news, editorials, letters and exchanges, and political advertisements. Some of the more important differences between. 


\begin{tabular}{|c|c|c|c|c|c|c|c|}
\hline Class. & & "A." & "B." & "c." & "D." & "E." & "F." \\
\hline I. News . . . & . & 52.2 & 56.3 & 54.7 & 55.4 & 58.3 & 53.0 \\
\hline a. War News. . & . . & 16.8 & 16.0 & I7. I & 17.2 & 18.6 & 20.3 \\
\hline b. General News & . & 20. I & 23.4 & 21.3 & 22. I & 22.3 & 20.3 \\
\hline I. Foreign . . & . & 1.2 & 2.6 & 1.9 & I. 4 & .6 & .7 \\
\hline 2. Political . & . & 5.4 & 6.0 & 5.4 & 6.I & 6.5 & 7.7 \\
\hline 3. Crime and Vice & . & 4. I & 4.3 & $3 \cdot 3$ & 2.2 & 3.2 & 2.7 \\
\hline 4. Miscellaneous . & . & 9.3 & 10.5 & 10.7 & 12.4 & I 2.0 & 9.2 \\
\hline c. Special News. . & 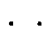 & I 5.3 & 16.4 & 16.3 & 16. I & 17.4 & 12.4 \\
\hline I. Business . . & . & 6.6 & 8.7 & 7.4 & 8.6 & 8.2 & 5.9 \\
\hline 2. Sporting . . & . & 6.0 & 4.5 & 5.8 & 4.7 & 6.9 & $4 \cdot 3$ \\
\hline 3. Social . . & 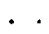 & 2.7 & 3.2 & 3.1 & 2.8 & 2.3 & 2.2 \\
\hline II. Illustrations & . & 7.6 & 3.2 & 3. I & 1.4 & 2. & I.7 \\
\hline III. Literature . & . . & 2.9 & 2.7 & 3.4 & 4.3 & 2.I & I.7 \\
\hline IV. Opinion . & . . & 5.2 & 6.0 & $7 \cdot 1$ & 8.6 & 8. & 9.3 \\
\hline a. Editorials . . . . & . . & 3.7 & 3.8 & 4.0 & $4 \cdot 3$ & 3.9 & 4.7 \\
\hline b. Letters and Exchang & & 1.5 & 2.2 & 3.1 & $4 \cdot 3$ & 4. I & 4.6 \\
\hline V. Advertisements . . & . & 32.0 & 31.8 & 31.7 & 30.3 & 29.5 & $34 \cdot 3$ \\
\hline a. Want .... & . & $7 \cdot 3$ & 6.0 & 5.0 & 3.0 & 3.6 & 4.0 \\
\hline b. Retail . & & 12.7 & 12.2 & 13.8 & 14.3 & 11.6 & 14.3 \\
\hline c. Medical . . . . . & & 4.7 & 3.7 & 3.6 & 2.9 & 2.8 & 3.7 \\
\hline d. Political and Legal & & .5 & I. 4 & 1.9 & I.o & 2.2 & $5 \cdot 3$ \\
\hline c. Miscellaneous . . & & 5.9 & 7.1 & 6.2 & 6.7 & 7.7 & $5 \cdot 7$ \\
\hline f. Self . . . . . . . & & I.I & I. 4 & 1.2 & 2.4 & 1.6 & 1.3 \\
\hline of papers analyz & ad & 25 & $3 I$ & $3^{8}$ & 12 & 22 & $1 \overline{8}$ \\
\hline
\end{tabular}

papers having more than 40,000 circulation and those having between 7,500 and 17,500 are as follows:

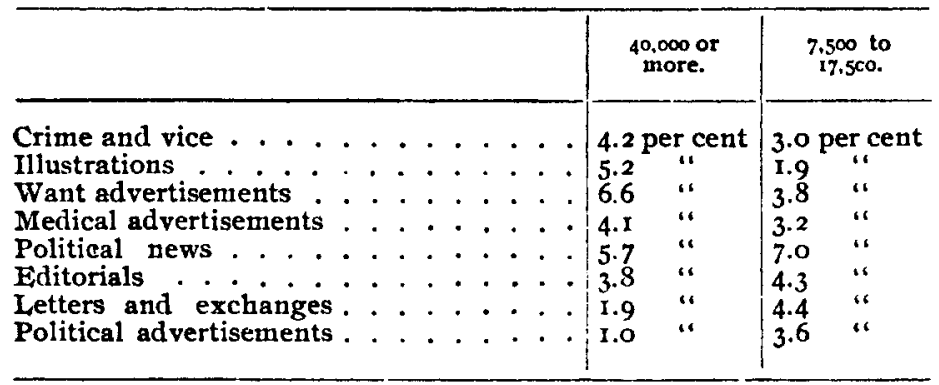

The comparison of the analyzed contents of a whole week's issues of two great dailies, the New York Times and the Chicago Record, reveals some of the differences that may exist between progressive high-class journals. The high 


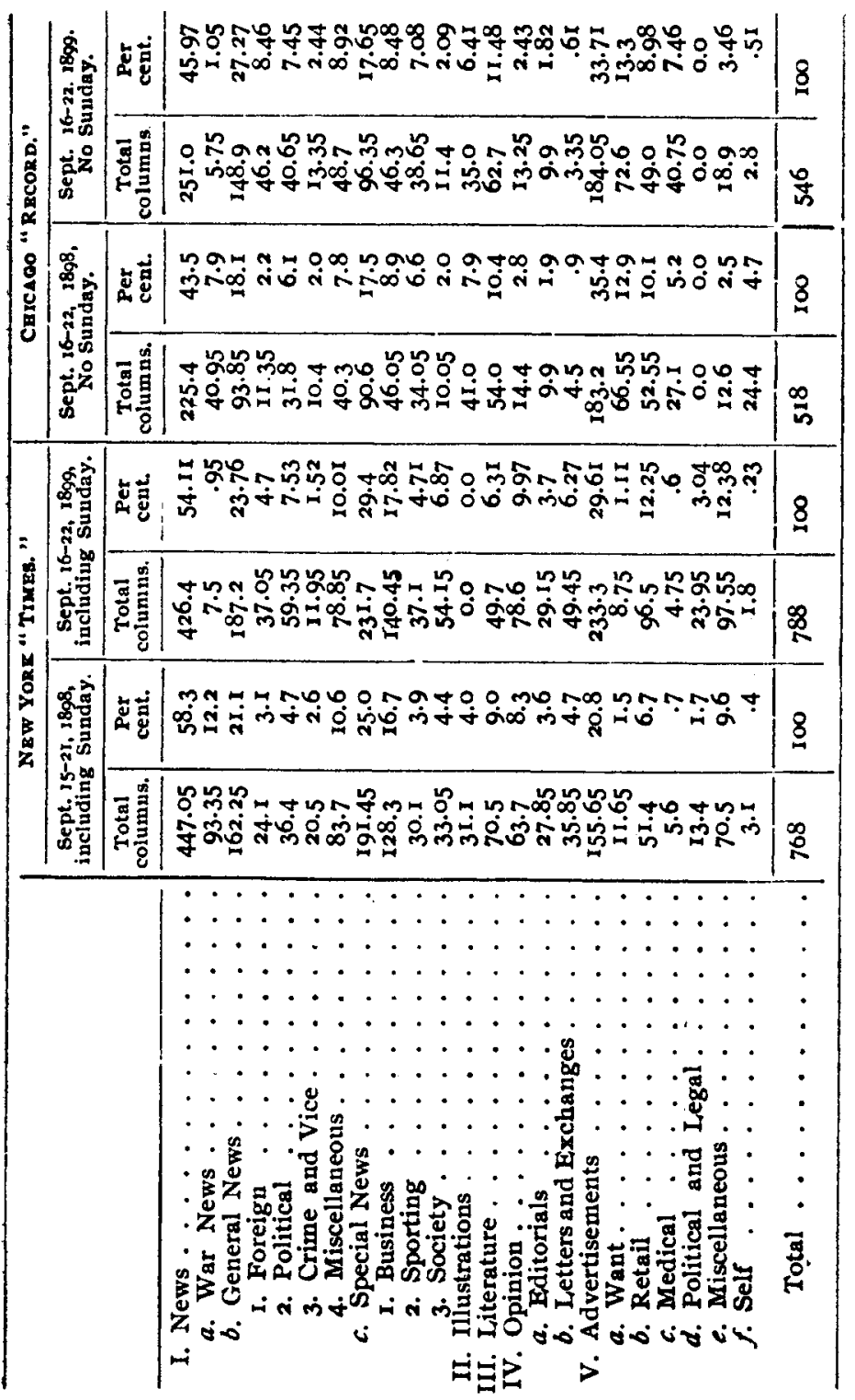


percentage of illustrations and literature in the Times for the week in 1898 are almost wholly due to the supplements. The Record has no Sunday edition and no supplements. A comparison of the week's issues in 1898 with a week's issues a year later shows principally the effect of peace in the decrease of war news and the increase of foreign and political news. The Times appears without any illustrations at all, the Sunday supplement having been discontinued. The great differences between the two papers in business news, editorials, letters and exchanges, and want, medical, and miscellaneous advertisements are noticeable in both years. The Times is a conservative journal. The Record, by the quantitative analysis of its contents, is made to appear "yellow." It is a notable example of the paper that has many of the characteristic features of yellow journalism minus its unscrupulous management and sensational spirit.

The most loyal newspaper man, as well as the most severe critic of newspapers, will admit that there are important differences in the quality of various journals. During the last few years the term "yellow journalism" has come into vogue. Presumably newspapers can be roughly classed as "yellow" and conservative; yet the definition of a yellow journal is a matter of some difficulty. In general, yellow journalism is about the same as extreme sensational journalism, and the latter may perhaps be defined as journalism that stimulates man's social senses merely for the sake of the pleasure and excitement attendant upon the stimulation. Sensational journalism possibly has its appropriate function in breaking down the false proprieties and properties of an individualistic civilization. But when set in motion by the unscrupulous greed of gain, and controlled by men who desire to get wealth or power by playing upon the passions and follies of their fellows, sensational journalism becomes undoubtedly pathological, a social vice the consequences of which are very grave. 
If we attempt to classify newspapers on the basis of the analysis of their contents made in the preceding pages, we are met by a disturbing fact, namely, that the character of journalism is determined more by the quality than by the subject of matter contained in the papers. For example, if the quantity of "literature" were taken as an index of the yellowness or the conservatism of papers, we should speedily find some of the yellowest and some of the most conservative journals falling into the same class. The quality as well as the quantity must be measured, and we find as much variation in the one as in the other. It is an amusing illustration of the difficulty of the statistical method that the writer had considerable trouble in getting a quantitative test which would make the New York Journal yellow and the New York Evening Post conservative. It is perhaps possible that a paper may be so sensationally conservative as to become almost yellow.

But, in spite of all the difficulties, an examination and comparison of contents will be of some use in measuring the relative influence of the two kinds of journalism. A comparison of fifteen yellow with fifteen conservative journals, selected by general appearance and reputation from all parts of the country, showed the following divisions of newspaper matter as characteristic of the two kinds of journalism, respectively:

$$
\begin{aligned}
& \text { Of yellow journalism } \ldots \ldots\left\{\begin{array}{l}
\text { News of crime and vice } \\
\text { Illustrations. } \\
\text { Want advertisements. } \\
\text { Medical advertisements. } \\
\text { Self advertisements. }
\end{array}\right. \\
& \text { of conservative journalism } .\left\{\begin{array}{l}
\text { Political news } \\
\text { Business news. } \\
\text { Letters and exchanges. } \\
\text { Miscellaneous advertisements. }
\end{array}\right.
\end{aligned}
$$

By adding the average percentages (for the whole country) of the classes of matter in each group we get 16.9 as 
the average percentage of yellow characteristics and 23.8 as the average of conservative characteristics. By classing journals as yellow or conservative according as they have more than the average percentage in one kind of characteristics and less than the average in the other, leaving as uncertain those which rise above or fall below the average in both, we are enabled for practical purposes to herd the horses, the asses, and the mules separately. Out of 147 papers analyzed we find 47 yellow, 45 conservative, and 55 uncertain journals. Their distribution according to news circles is shown in an accompanying table. Of twenty

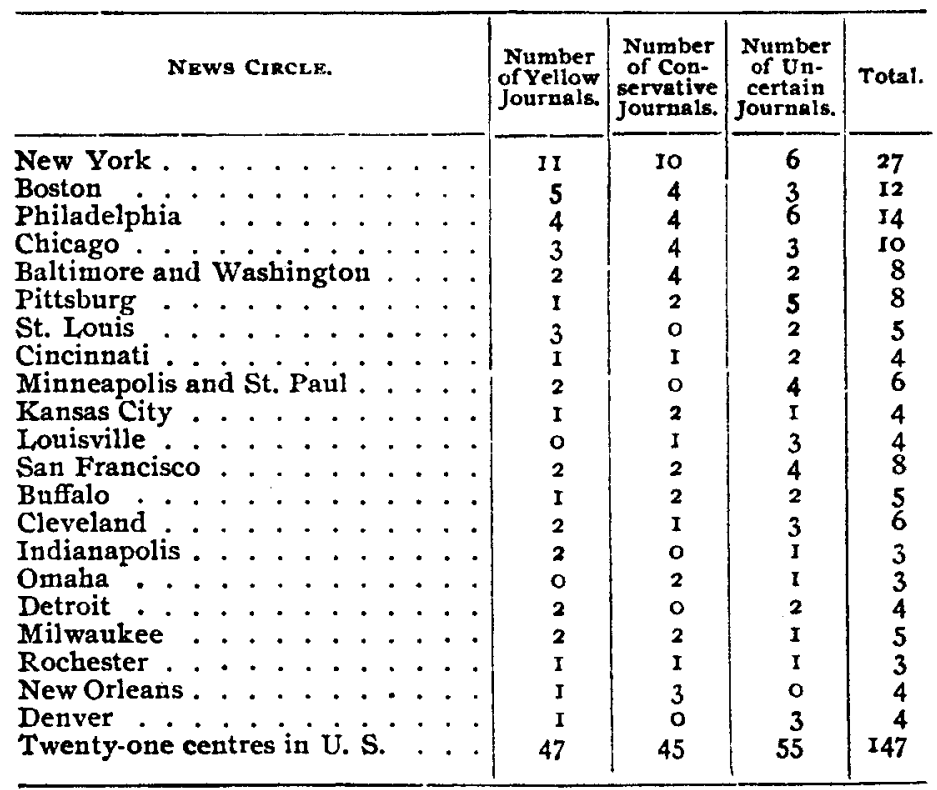

papers classed as "uncertain" published in the New York, Boston, Philadelphia and Pittsburg circles, eighteen have less than the average percentage of both yellow and conservative characteristics; while of eight such papers published in 
the San Francisco, Denver and Omaha circles, all have more than the average percentage of both. This fact indicates that journalism is less differentiated in the West than in the East, extremes meeting, not only in the same city, but even in the same papers. An illustration of this fact may be taken from W. R. Hearst's two papers, the San Francisco Examiner and the New York Journal. In these two papers the percentages are:

Examiner, yellow, 37.6 per cent; conservative, 27.2 per cent.

Joumal, yellow, $3^{8.0}$ per cent; conservative, I4.8 per cent.

Yellow journals, have, as a rule, a larger circulation than conservative journals, as shown by the accompanying table.

\begin{tabular}{|c|c|c|c|c|c|c|c|}
\hline Class. & "A." & "B." & "c." & "D." & " $\mathbf{E}^{*}: "$ & "r." & All. \\
\hline $\begin{array}{l}\text { Yellow . }: \cdot \cdot \cdot \cdot \cdot \\
\text { Conservative } \cdot \text {. } \\
\text { Uncertain . }\end{array}$ & $\begin{array}{r}17 \\
3 \\
5\end{array}$ & $\begin{array}{r}\text { ro } \\
8 \\
13\end{array}$ & $\begin{array}{r}12 \\
9 \\
18\end{array}$ & $\begin{array}{l}I \\
7 \\
4\end{array}$ & $\begin{array}{r}4 \\
\text { I0 } \\
8\end{array}$ & $\begin{array}{l}3 \\
8 \\
7\end{array}$ & $\begin{array}{l}47 \\
45 \\
55\end{array}$ \\
\hline Total ..... & 25 & $3 I$ & 39 & J 2 & 22 & I8 & 147 \\
\hline
\end{tabular}

A comparison of the prices of newspapers shows that out of a total of 147,66 are sold for one cent apiece, 47 for two cents, 15 for three cents, and 19 for five cents. All but two of the five-cent papers are published in the San Francisco, Denver, Omaha, and New Orleans circles. The yellow journal is generally cheaper than the conservative journal, as shown in the accompanying table. As was to be ex-

\begin{tabular}{|c|c|c|c|c|c|}
\hline Price of Journals. & 1 cent. & 2 cents. & 3 cents. & 5 cents. & All. \\
\hline $\begin{array}{l}\text { Yellow : } \cdot \cdot \cdot \cdot \cdot \cdot \cdot \\
\text { Uncertain } \cdot \cdot \cdot \cdot \cdot \cdot \\
\text { Conservative }\end{array}$ & $\begin{array}{l}30 \\
24 \\
12\end{array}$ & $\begin{array}{l}\text { I2 } \\
\text { I8 } \\
\text { I7 }\end{array}$ & $\begin{array}{l}2 \\
4 \\
9\end{array}$ & $\begin{array}{l}3 \\
9 \\
7\end{array}$ & $\begin{array}{l}47 \\
55 \\
45\end{array}$ \\
\hline Total . . . . . & 66 & 47 & I5 & 19 & I47 \\
\hline
\end{tabular}


pected, low price and large circulation go together, as shown by the table of prices according to circulation classes. Of

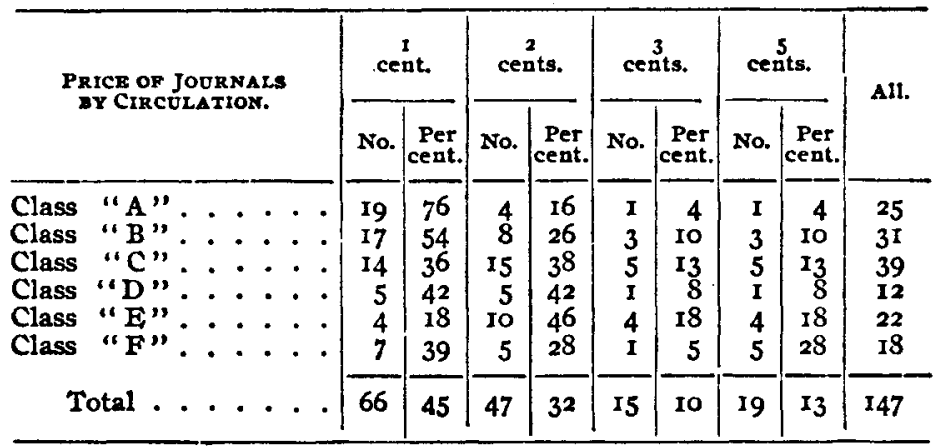

the 147 papers, 69 were published in the morning and 78 in the evening. Yellow journals are predominantly evening papers, while the time of day when issued makes no appreciable difference in circulation. Of the 147 papers, 87 pub-

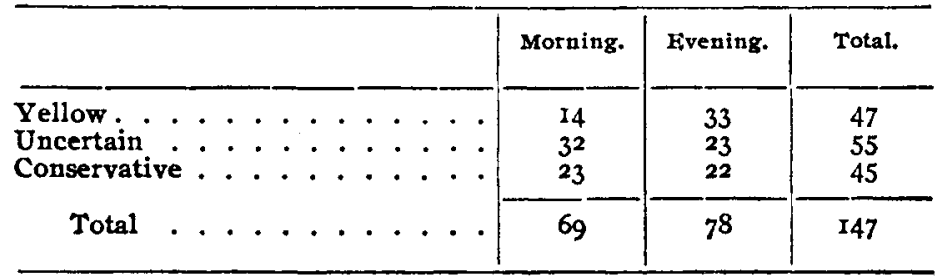

\begin{tabular}{|c|c|c|c|c|c|c|}
\hline & & & & Morning. & Erening. & Total. \\
\hline $\begin{array}{l}\text { Class " } \mathrm{A} \text { ", } \\
\text { Class "B " } \\
\text { Class "C", } \\
\text { Class " } \mathrm{D} \text { " } \\
\text { Class " } \mathrm{E} \text { ", } \\
\text { Class " } \mathrm{F} \text { " }\end{array}$ & 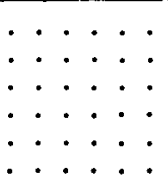 & 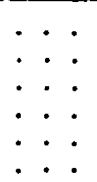 & 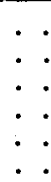 & $\begin{array}{r}12 \\
19 \\
17 \\
4 \\
10 \\
7\end{array}$ & $\begin{array}{r}13 \\
12 \\
22 \\
8 \\
12 \\
11\end{array}$ & $\begin{array}{l}25 \\
31 \\
39 \\
12 \\
22 \\
18\end{array}$ \\
\hline All Clas & es..... & • & . . & 69 & 78 & 147 \\
\hline
\end{tabular}

lish a Sunday edition, 56 a weekly or Saturday edition, eleven a semi-weekly edition, and two a thrice-a-week edi- 
tion. A larger proportion of yellow journals issue Sunday editions, while a larger proportion of conservative journals issue weekly editions.

\begin{tabular}{|c|c|c|c|c|c|c|c|c|c|c|c|}
\hline \multirow{2}{*}{\multicolumn{2}{|c|}{ Edrtions. }} & \multicolumn{2}{|c|}{ Daily. } & \multicolumn{2}{|c|}{ Sunday. } & \multicolumn{2}{|c|}{$\begin{array}{l}\text { Weekly or } \\
\text { Saturday. }\end{array}$} & \multicolumn{2}{|c|}{$\begin{array}{c}\text { Bi- } \\
\text { weekly. }\end{array}$} & \multicolumn{2}{|c|}{$\begin{array}{c}\text { Tri- } \\
\text { weekly. }\end{array}$} \\
\hline & & No. & $\begin{array}{l}\text { Per } \\
\text { cent. }\end{array}$ & No. & 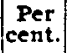 & No. & $\begin{array}{l}\text { Per } \\
\text { cent. }\end{array}$ & No. & $\begin{array}{c}\text { Per } \\
\text { ceut. }\end{array}$ & No. & $\begin{array}{l}\text { Per } \\
\text { cent. }\end{array}$ \\
\hline $\begin{array}{l}\text { Yellow : } \\
\text { Uncertain } \\
\text { Conservative }\end{array}$ & : & $\begin{array}{l}47 \\
55 \\
45\end{array}$ & $\begin{array}{l}100 \\
100 \\
100\end{array}$ & $\begin{array}{l}29 \\
36 \\
22\end{array}$ & $\begin{array}{l}62 \\
67 \\
49\end{array}$ & $\begin{array}{r}9 \\
23 \\
24\end{array}$ & $\begin{array}{l}19 \\
43 \\
53\end{array}$ & $\begin{array}{l}I \\
3 \\
7\end{array}$ & $\begin{array}{r}2 \\
6 \\
16\end{array}$ & $\begin{array}{l}\text { I } \\
\text { o } \\
\text { I }\end{array}$ & $\begin{array}{l}2 \\
0 \\
2\end{array}$ \\
\hline Total . . & . & 147 & 100 & 87 & 59 & 56 & 38 & II & 7 & 2 & I \\
\hline
\end{tabular}

We have already seen that St. Louis is a notable centre of yellow journalism. Every one of the five leading dailies of St. Louis gives more than the average share of space to "yellow" characteristics. It is related that a former editor of the Globe-Democrat who had a great influence upon St. Louis journalisn, once defined the most successful newspaper manager as the man who best knew where hell was going to break out next, and had a reporter on the spot. Possibly this anecdote will give the desired key to the nature of yellow journalism, though we might add, that nowadays, when hell shows no signs of eruption, the successful newspaper manager sends a reporter to "raise" it.

If we were to count as yellow journals of the deepest dye those which give more than one-third of their space to yellow matter, we should find seven-four owned by W. R. Hearst, and two owned and one founded by Joseph Pulitzer. This fact, that the seven yellowest great dailies in the United States have been or are now under the control of one of two men, is an indication of the immense opportunity for the expression of individuality in journalism. The New York World and the New York Journal have an incalculable influence in the United States. During the late war they claimed a daily circulation of more than a million 
copies each, and they were hawked upon the streets of distant cities. Their influence does not arise from popular confidence in them, but is rather the influence of association and success. Everywhere, like omnipresent rowdies, these papers make themselves felt.

An individual influence of quite a different character has been exercised by the New York Sun under the control of the Danas. The Sun is, in most respects, a conservative paper, though possessed of a brilliant individuality. This paper furnishes more "exchanges," most of which are articles of some length and value, than any other paper in the United States. In the papers analyzed 75 exchanges were

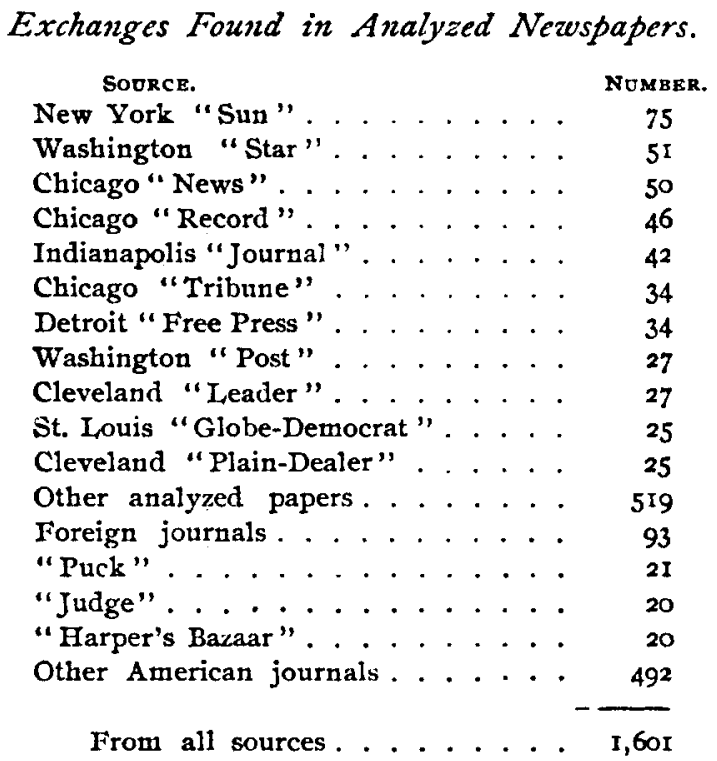

taken from the $S u n$, while only 15 and 14 were taken from the World and the Journal, respectively. The pre-eminence of the Sun has been due, no doubt, to its literary excellence. 
Some further indication of newspaper individuality may be gleaned from a few samples of journalistic mottoes. The Sun's motto until two or three years ago was, "If you see it in the 'Sun,' it's so." Other examples follow:

New York Journal, "An American newspaper for the American people."

New York Times, "All the news that's fit to print."

Boston Post, "The representative Democratic paper of New England;" "with a mission and without a muzzle."

Worcester $S p y$, "The spy should have the eye of Argus; he is honorable if he do but look to the welfare of the commonwealth."

Brooklyn Eagle, "We must not conform to governments. Governments are intolerable unless they conform to us."

Philadelphia North American, "American in everything and always for the people;" "The oldest daily newspaper in America;" "You can believe what you read in the 'North American.' "'

Buffalo News, "Some papers give all of the news part of the time, and some papers give part of the news all of the time. The 'News' is the only paper that gives all the news all the time."

Baltimore Sun, "L,ight for all."

Baltimore American, "We build."

Louisville Post, "If new and true, not otherwise-a Democratic newspaper."

St. Paul Dispatch, "You may rely upon the truth of the 'Dispatch' news and bulletins. No fakes tolerated."

Kansas City Journal, "By the way, the war has not interfered with making Kansas City a good place to live in."

New Orleans Item, "The 'Daily Item' is the paper that defends the interests of all classes."

An examination of the editorial columns of the papers analyzed revealed the extent to which editorial comment is 
devoted to controversial matters. The editorials with title were upon the following general subjects:

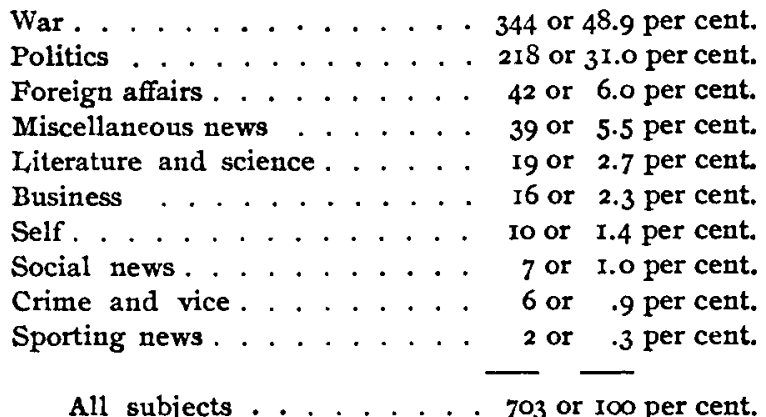

The average number of editorials for each paper was 4.8, with a considerable preponderance in favor of conservative journals. A comparison of the papers does not show any marked differences in the subjects of editorial comment in yellow and conservative sheets.

One of the most encouraging signs in the journalism of to-day is the excellence and apparent success of the "Home Study Circle," conducted by Professor Seymour Eaton, of Drexel Institute, and published in the Chicago Record and about a dozen other papers from Newark, N. J., to Denver, and from Minneapolis to New Orleans. The studies are written by specialists, among whom are many eminent college men. The subjects of study are numerous and interesting, including literature, science, history, biography, art, government, political economy, and industry. The educational value of this movement ought to be very great. A number of papers which do not publish the "Home Study Circle" have literary and scientific features, one of the most common being the "household" page, on which is sometimes published a copyrighted menu. Another valuable feature sometimes found in newspapers is the question bureau. One recent development of New York journalism is the Sunday or Saturday "Magazine Supplement," which 
is generally calculated to popularize art. Although the New York Times, with which this feature originated, has discontinued its Sunday supplement on the plea that henceforth it wishes to be a newspaper strictly, the Times supplement has already had a wide and probably beneficial influence on the Sunday newspaper. The Times still issues an excellent Saturday supplement, devoted to the "review of books and art," and a Monday supplement, or weekly financial and commercial review.

If a newspaper is to have an individual influence, that is, if it is to be a leader of public opinion rather than a mere reporter of events, it should exercise its power through the editorial columns. The intelligent reader can tolerate any $k$ ind of editorial vehemence better than the discoloration of news. The most powerful influence that lends itself to the discoloration or suppression of news is, in general, partisanship, whether it be sincere or subsidized. The $\mathbf{1 4 7}$ papers here under examination show political affiliations as follows:

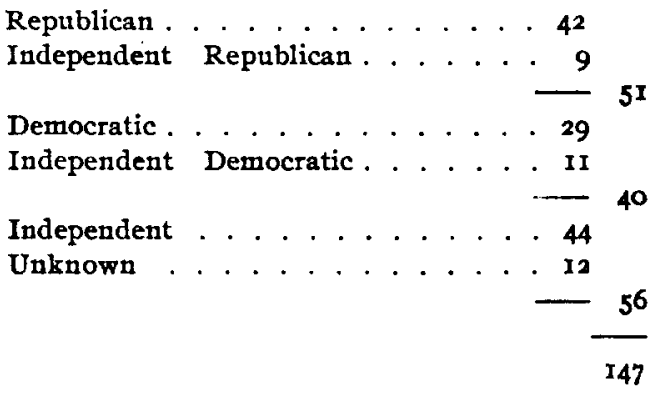

The parties divide the honors about equally so far as circulation and yellow journalism are concerned, though the Democratic party has slightly the better of it in both particulars. It should, perhaps, be noted as a sign of the development of a new partisanship that eleven out of the I 47 papers carry the "Union label." Three of these papers are in Louisville and two in Milwaukee. 
Although it has not been within the scope of this investigation to inquire into the details of news-gathering, one or two significant facts appear from a study of the papers themselves. During the war a set of newspapers in different parts of the country would publish syndicate dispatches other than those of the Associated Press. The Herald, the World, and the Journal, all of New York, were each at the head of a war news syndicate comprising eight or ten leading papers in nearly as many cities. There was also the "'Scripps-McRae League," which is apparently a permanent syndicate composed of six papers published in the central West. These papers seem to draw upon a central editorial bureau to a certain extent. At any rate, an identical "leader" entitled "Governor Scofield's Cow" appeared in both the Cleveland Press and the Kansas City World, members of the League.

Something has already been said of the possibilities of individual leadership in journalism. The other side of the paradox is that the effacement of the individual often seems so complete and so hopeless as to discourage ambitious young men from entering the journalistic profession. As the business of collecting and distributing news gets better organized, it is undoubtedly true that the call for strong individuality in journalism grows less. The newspaper business is, perhaps, getting farther and farther away from the profession of journalism. Certainly the established newspapers are coming to be more and more institutional. It requires a large outlay of capital to make a newspaper succeed, and, without independent means, it requires great, perhaps almost impossible, adaptability in the thoroughly intelligent and conscientious man to walk the path that leads to the editorial chair. The newspaper, which is preeminently a public and not a private institution, the principal organ of society for distributing what we may call working information, ought not to be controlled by irresponsible individuality. Those newspapers that are partisan 
organs are, in large measure, politically controlled, and in so far as they are really responsible to their party, they perform a more important public function than they could if subject to the caprice of the individual owner or editor. At the same time, a journal whose news columns are prostituted to the interests of a faction or a "hoss" does not deserve the name of newspaper. The same is true of a journal subsidized by private interests of any kind to tamper with the news. For these reasons, complete independence of private or factional interests, and a consequent subordination of the editorial page to the news column, is coming to be widely recognized as the ideal of journalism.

Let us see what the function of news is. All information that is useless is worse than useless, because it detracts one's attention from his work to no purpose. But the retail merchant often looks into the daily paper to find the latest market prices, and acts upon the information obtained. The boy out of work searches the want columns and gets direction in his hunt for a situation. Probably almost everyone sometimes goes to the newspaper for information that will immediately affect his action. Yet the great mass of the information we get in reading the papers affects our action only vaguely and remotely, if at all. It would probably be much more advantageous, for most people, to read a concise and accurate review of foreign news and general home news once a week or once a month than to glance every day through columns of unverified reports and surmises about what is happening or going to happen. Some periodicals published weekly, monthly, or quarterly, give such reviews at the present time, and a few newspapers assist their readers by printing on the front page either a table of the principal contents of the paper or a digest of the day's news. Indeed, the system of elaborate headings, which in yellow journals sometimes extend clear across the page and take up a large share of the space, is de- 
signed to catch the eye and relieve the general reader from the trouble of plodding through the lengthy dispatches in fine print. One of the characteristic methods of yellow journalism is to prostitute the headlines to an unworthy function, either by making them unduly prominent and thus forcing attention or by making them exaggerate or misrepresent the contents of dispatches. In any case, headlines and daily summaries are the editor's abbreviations of the daily news and rumors, and are less trustworthy, though more accessible sources of information than the news columns themselves. The reader of the daily papers is often at a loss to give any connected account of the course of important events simply because he has had a rapid series of vague and conflicting impressions from hastily looking over the headings of daily dispatches. It is clear that presentday journalism, with its numerous daily editions and its fierce competition for priority in the publication of news, has greatly overdone the matter. When two or more papers get to "running" each other, they often lose all sense of responsibility to the public, and their competition becomes simply a game for the opportunity of self-gratulation. There is at present a general tendency to exaggerate the importance of being "up-to-date." We are so thoroughly up-todate that we might about as well celebrate our funerals and see who can get to heaven first. May we not define the appropriate function of the newspaper thus? The newspaper should render easily accessible to the individual all widely-interesting news as promptly as is consistent with accurate reporting, and should furthermore give concise reviews of public events just passed. In other words, news should be for use, not principally for stimulation. The newspaper should not endeavor to magnify the importance of news for the purpose of creating interest and increasing its sales. This latter proposition, though apparently reasonable, seems almost ludicrously impracticable. It is evident that we have struck the bread-and-butter problem. 
Here we get into inevitable controversy, for competition, "the life of trade," is brought into court.

The vital question with reference to the newspaper business is, from the social standpoint, the question of control. Who shall be responsible for the newspaper? It is rationally absurd that an intelligent, self-governing community should be the helpless victim of the caprice of newspapers managed solely for individual profit. The practical newspaper man would choose to publish a partial and inaccurate account of some new occurrence to-day rather than wait till to-morrow and be able to publish a full and exact account of the affair. Furthermore, an earlier garbled report makes a later complete report unavailable-it is no longer news. Why are these things so? Simply because the sine qua non of successful competitive journalism is believed to be not to give an accurate report, but to give the first report. The American people must dearly love the freedom of the press, or we should have heard before now much talk of government control or operation of the newspaper. Censorship is, however, distasteful to the people even when apparently necessary in time of war. Nevertheless, the newspaper business, if not a "natural monopoly," is at least a business in which a large aggregation of capital and a widespread and unified organization for news-gathering and news-distribution is essential to success. The function of the newspaper is so predominantly public and its service so universally requisite, that many government undertakings are far less truly political. When we assail political corruption we generally blame either the "politicians" or the "citizens." If the latter, we practically concede that there is no immediate remedy for corruption available. In attacking the abuses of journalism, there is a like tendency either to put the blame on the newspaper managers or on the "public." If we blame the "public" solely, there is no apparent remedy; for the newspapers themselves are coming more and more to be the principal organs through 
which public tastes are formed and appeals to public intelligence made. The tool is master of the man, and, too late, we blame the man. It is certainly probable that a newspaper directly responsible to an intelligent and conscientious public would have to be a good journal in order to succeed. In a perfect democracy the newspaper business would regulate itself. But, unfortunately, the "public" is not altogether intelligent and conscientious, and for that reason the newspaper becomes an organ of dynamic education. It would be treachery to social ideals for schoolteachers to choose and pursue their profession simply as a money-getting enterprise. The same is true of journalism. Responsibility must attach to this public function.

If the people trusted their chosen governors and were themselves united in their support of the public welfare, they would undoubtedly be willing to put the newspaper business, like education, into government hands, though not as a monopoly. In fact, however, we as a people still regard government as a necessary evil. It is my belief that the salvation of our cities depends on the displacement of this view by the view that government, the co-operative organization of all for the benefit of all, is a necessary good. Newspaper competition is, as we have seen, most severe in the largest cities, and there also the need of a new development of social consciousness is most pressing. Weekly and monthly journals appeal to a more widely scattered constituency, and for that reason do not supply to the city man even imperfect summaries of city news and municipal doings. For such summaries he must depend on himself or on municipal reports. Annual reports for free distribution are usually published by the large cities. Two American cities, New York and Boston, publish a daily or weekly "City Record," containing an account of all municipal business. These two cities also have instituted statistical bureaus for the collection and distribution of what we may call general municipal news. In Cleveland, at least, bulletins of important events are posted daily in the public 
library. In another direction also government is encroaching upon the field of the newspaper. In the establishment of public employment bureaus under state authority in Chicago and some other cities, we see an entrenchment upon the "want ad" columns of the daily newspaper. Is it at all unlikely that, following out these lines of activity, government, particularly in cities, will sooner or later put into the field newspapers to cover at least the news of local business and politics and be available for use in the public schools, the public libraries, the city offices, and elsewhere? If such journals could be kept free from factional control and from the debauching influence of irresponsible newspaper competition, they would be of great service in the education of the "public" and in the control of private journals.

But let no one imagine that government operation is here prescribed as a panacea for the evils of irresponsible journalism. Mr. Hearst has worked like a hero to make the New York Journal the yellowest and most successful journal in the United States. Practically, he "endowed" yellow journalism. The endowment scheme for newspaper reform is not generally accepted as practicable. There is a feeling that journalism should be a business, and that news-gathering and distribution should pay for itself. Those who object to the endowment plan should, however, reflect upon the question whether or not the public has not already been "endowed" by someone when a newspaper can be bought regularly for less than the cost of the paper on which it is printed. Possibly the secret of many newspaper evils lies in the fact that the advertisers and the readers can be played off against each other. In order to get a large circulation with which to catch advertisements, the price of the paper is reduced, its size increased, its headlines made sensational, and illustrations introduced to stimulate the flagging senses of the reader. Then, as advertisements flow in at increased rates, the price of the paper can be further reduced and its attractions multiplied. Under these circumstances advertisements of doubtful character are accepted 
as a matter of course. Ought not the advertising sheet and the newspaper be separated so that each would have to pay for itself? Advertisements that are really of general interest to the public should, on such a theory, be published as news. At any rate, the chief argument against the endowment of a newspaper seems to rest on a misconception of present conditions, and there is no apparently satisfactory reason why some of our surplus millionaires should not emulate the example of $\mathrm{Mr}$. Hearst, with this difference, that they devote their money, their brains, and their energy to the promotion of public intelligence instead of the stimulation of public passion. In the meantime it may be possible to work toward a better journalism by introducing or strengthening the legal responsibility of newspapers for publishing only reliable news.

We ought not to despair of newspaper reform. We need a development of the sense of social responsibility for the use of brains and money. If this were general, government journalism would be safe, though perhaps unnecessary. While this sense of responsibility manifests itself in a few individuals only, they have all the greater opportunities for distinguished social service. The efforts of reformers are often decried on the plea that we are in the grasp of inevitable tendencies and that there is no use of trying to turn the natural course of civilization. Do we not forget that the instruments of our present civilization were invented and the direction of our development turned in particular ways by the herculean efforts of individuals, formers and reformers? Anyhow, there is still room for evolutionary methods; for good is mixed with the evil of even the yellowest journals, and many successful journals still preserve their fair name. When society is well organized, social intelligence will be better organized than it now is. The advance of the newspaper toward exact reporting will go hand in hand with the exact organization of human affairs. 